\title{
Online Trading: Using Supply Chain Data in Capital Market Study Group
}

\author{
Hisnol Jamalia , Victor Pattiasina ${ }^{b^{*}}$, Muhamad Yamin Noch \\ aSTIEM Bongaya, Makasar, Indonesia. E-mail: hisnol.jamali60@gmail.com \\ b*Universitas Yapis Papua, Indonesia. E-mail: Pattiasina6@gmail.com \\ cUniversitas Yapis Papua, Indonesia. E-mail: abienoch12@gmail.com
}

Article History: Received: 11 January 2021; Accepted: 27 February 2021; Published online: 5 April 2021

\begin{abstract}
This study aimed at examining as well as analyzing the use of the online trading model. The variables of the current study were attitude and perception of the use of online trading, moderated by university students' interests in PapuaIndonesia. The population of this study were five universities namely, STIEM Bongaya Makasar, Universitas Yapis Papua Jayapura (UNIYAP); Universitas Cenderawasih (Uncen); Universitas Science \& Technology Jayapura (USTJ); Universitas Ottow \& Geissler Papua (UOGP). The research sample was 97 students incorporated in the Capital Market Study Group and Trading Shares listed on the Indonesia Stock Exchange. It was a kind of incidental sampling. The data were analyzed through SPSS with two path analysis techniques. The results showed that attitude has a positive and significant influence on the use of online trading. In contrast, the perception of usage does not significantly affect the use of online trading. Next, interest in mediating the effect of attitude towards the use of online trading, and interest in partially mediating the influence of the perception of online trading usage.
\end{abstract}

Keywords: Attitude, Usage Perception, Interest, Online Trading, Supply Chain Online.

\section{Introduction}

Investors do use not only the estimation of the investment prospects but also use the psychological estimation factors. The psychological factors, in a practical view, influence decision making in determining investments. An example that is quite interesting is the existence of bounded rationality in investing. Efficient market hypotheses and the thought that the psychology factor has impacted the market decision is still debatable in financial theory. Therefore, investment analysis that uses psychology and financial science has been conducted. The study called Behavioural Finance study.

On the other hand, some investors sell shares as soon as they appear to have profit and hold the shares for a long time when the stock price falls (Shefrin, 2005). The existence of these psychological factors affect investment interest and the results to be achieved. This case shows that investors, psychologically, do not want to experience a loss on their investment.

Shefrin (2005) defines behaviour finance as the study of how psychological phenomenon affects financial behaviour. Nofsinger (2001) defines financial behaviour, namely learning how humans behave in a financial setting. Specifically, the theory studies how psychology influences financial, corporate, and financial market decisions. Both concepts state that financial behaviour is an appropriate approach that explains how humans make investments. In other words, finance matter is influenced by psychological factors.

Discussing financial problems is inseparable from discussing the capital market. In Indonesia, the capital market has become big business among successful entrepreneurs engaged in the capital market. Stock trading becomes the main thing traded because the orientation in the capital market is very profitable. The capital market does not look at the background of traders. Entrepreneurs, employees, labourers, unemployed, and university students may be involved in the market. Any universities students can make transactions in the capital market. The Indonesia Stock Exchange (IDX) is one of the Indonesian capital market institutions that provide capital market data and information services.

In Indonesia, the Indonesia Stock Exchange (IDX) has continued to grow since the securities/stocks are increasingly in demand. The transactions per month, in Papua- Indonesia, by November 2017, reach 50 to 70 billion. This shows that the enthusiasts of the capital markets in Papua are increasing. In Jayapura City-Indonesia, by 2018, it is known that there have been 5 Investment Galleries in several universities. The investment galleries were established in collaboration with IDX, Stock Securities, and the other relevant tertiary institution. They are called the Capital Market Study Group (CMSG).

The CMSG was established based on the interests of students who trade stocks. With the existence of CMSG, students can discuss stock analysis techniques, stock psychology. They discussed it under the supervising of their 
lecturers. Furthermore, they also conduct stock transactions. In trading shares, each student has their own and attitudes.

Furthermore, it varies in responding to market conditions, both in the state of the uptrend, downtrend, sideways, or oversold/overbought market. In its implementation, it was found that there were students who joined CMSG but did not understand how to use online trading. Some students have also joined CMSG but they are not interested in doing transactions in the capital market. On the other hand, some students do not respond to stock price movements and conditions of the capital market.

For this reason, the researchers intend to research "The Use of Online Trading in the Capital Market Study Group" which involved CMSG in universities in Makasar city and Jayapura city, including STIEM Bongaya Makasar, Universitas Yapis Papua Jayapura (UNIYAP); Universitas Cenderawasih (Uncen); Universitas Science \& Technology Jayapura (USTJ); and Universitas Ottow \& Geissler Papua (UOGP).

\section{Theoretical Review}

Financial behaviour is a science that studies how humans respond and react to information to make decisions that can optimize the rate of return. Elements of human attitudes and actions are determinants in investing (Agustin \& Mawardi, 2014). Humans, based on traditional financial, always think about financial behaviour (Manurung, 2012) while Shefrin (2005) states that the differences in Financial Behaviour and Traditional Finance are shown by two issues for asset prices, namely (1) sentiment and (2) utility expectations. Based on Financial Behaviour view, the sentiment is the dominant factor in the occurrence of prices in the market for consumer behaviour. At the same time, Traditional Finance states that the sentiment is asset prices that are always associated with fundamental risk or time-varying risk aversion. Utility expectations, based on the view of Traditional Finance, is a maximizing utility expectation. In the other side, based on the view of Financial Behaviour, Utility Expectations is not suitable.

According to Olsen (1998), financial behaviour does not define "rational" behaviour or define decision making as a bias or error; but rather to understand and predict the systematic implications of financial markets from a psychological point of view. However, Olsen (1998) stressed that there is no theory of integrated behavioural finance so far. What is found in the literature is limited to identifying the attributes of decision making in investing in the market.

Fuller (2000) explains three important points in behavioural finance. The first explains that behavioural finance is a combination of classical economics and finance with psychology and the science of decision making. It should be noted that the science of decision making also develops with the times, so that the application of classical economic theory which is relatively standard, varies along with the times. Furthermore, Fuller (2000) explains that behavioural finance is an attempt to explain what causes some financial anomalies that have been seen and recorded in financial literacy. Many case studies and observations from previous events are expected to be the basis for the future development of behavioural finance theory. It is hoped that these financial anomalies can be explained through new theories. Finally, behavioural finance is a field of study that explains how investors systematically make wrong judgments or mental mistakes.

Ritter (2003) explains some of the biases that affect human behaviour in general. They are presented as follows. First, heuristics, that is to simplify the decision-making process. Humans tend to make a simple standard rule for making decisions. For example, the 80/20 rule that was first revealed by Italian economist, Vilfredo Pareto. Financial managers widely used it to develop their portfolios. Second, overconfidence; Ritter (2003) explains that investors tend to over-invest only in stocks they are familiar with. Investors tend to feel too confident. Third, framing; It states that human thinking patterns can be manipulated to present concepts that are packaged more interesting. The further example, Ritter (2003) explains that a "coin toss" game that rewards $\$ 50$ in tails and a prize of $\$ 50$ is bundled with a loss of $\$ 50$ if it exits heads. Although both of the above can cause a loss of $\$ 50$, investors' behaviour will be different for each bet.

Fourth, representativeness; It states that investors tend to underestimate the long term average and pay more attention in the short term. Therefore, investors tend to "overreact" in the short term Fifth, conservatism. Bodie et al. (2008) explain that investors tend to react "too slowly" about developments. Contrary to the bias of representativeness, investors become " underreact " because of conservatism.

\section{Research Method}

This research applied a quantitative method with a probabilistic technique. To gain sample, incidental sampling technique was applied, while to gain data, research instruments were applied. Next, to analyze data, a quantitative statistical method was applied. It aimed at examining the hypotheses. 


\subsection{Population and Samples}

The population is a combination of all elements that formed events, things, or people who have similar characteristics that are the centre of researchers' attention since it is seen as a universe of research (Ferdinand, 2006). The population of the current study were students at several universities in Makasar and Papua- Indonesia namely, STIEM Bongaya Makasar, Universitas Yapis Papua Jayapura (UNIYAP); Universitas Cenderawasih (Uncen); Universitas Science \& Technology Jayapura (USTJ); Universitas Ottow \& Geissler Papua (UOGP). The total population were 200 students. Next, the sample was chosen following Slovin formula. The formula that was used for determining samples is presented as follows:

$$
n=\frac{N}{1+\left(N \times e^{2}\right)}
$$

Note:

$\mathrm{n}=$ Sample size $/$ number of respondents

$\mathrm{N}=$ population size

$E=$ Percentage of allowance for accuracy of sampling errors that can still be tolerated; $e=0.05(5 \%)$

Based on the application of the formula, the calculation is presented as follows.

$$
\begin{gathered}
n=\frac{200}{1+\left(200 \times 0,05^{2}\right)} \\
n=\frac{200}{1,5}=133,33
\end{gathered}
$$

On the above calculation, respondents of the current study were adjusted to 134 people, or around 7, $2.39 \%$ of the total population. This was conducted to facilitate data processing and for better examination results. Next, using the sample, the current research was conducted. The model of the research is presented in the following Figure (1).

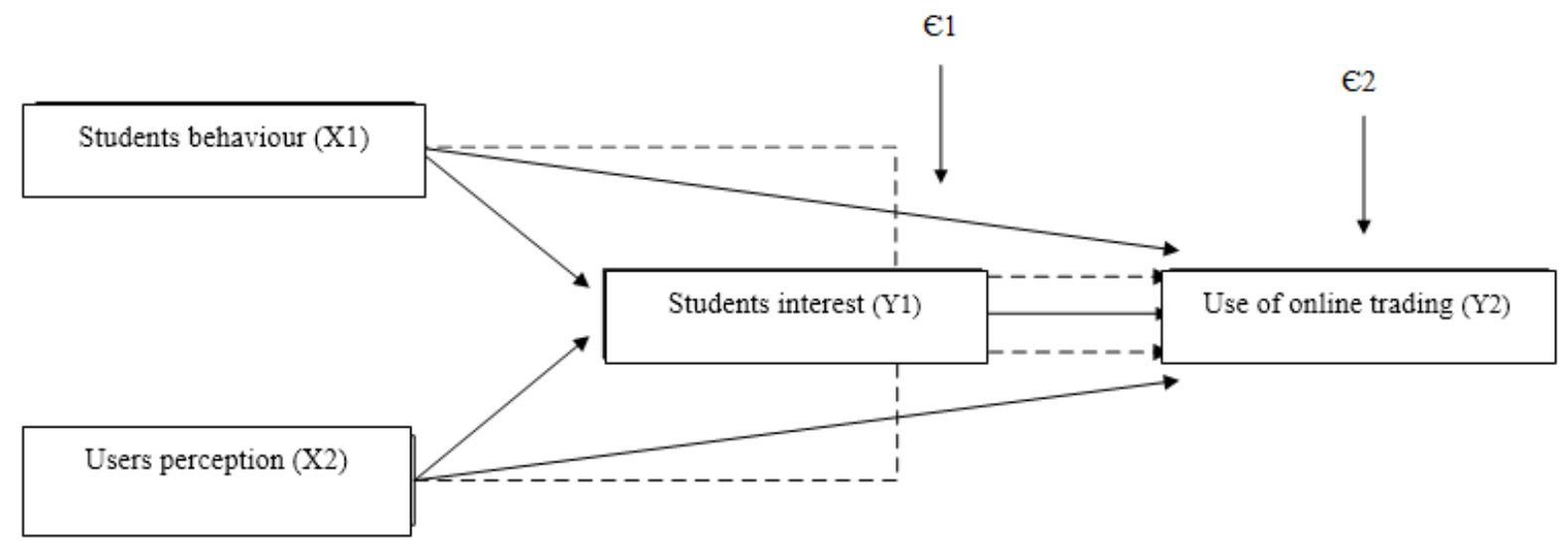

Fig. 1 The model of the research

\subsection{Research Hypotheses}

The current research has seven hypotheses that need to be examined. The hypotheses are presented as follows.

$\mathrm{H}_{1}$ : Student attitude positively influences interest.

$\mathrm{H}_{2}$ : The perception of use has a positive effect on interest.

$\mathrm{H}_{3}$ : Attitude has a positive effect on the use of online trading.

$\mathrm{H}_{4}$ : Perception uses a positive effect on the use of online trading.

$\mathrm{H}_{5}$ : Interest has a positive effect on the use of online trading.

$\mathrm{H}_{6}$ : The attitude has a positive effect on online trading through students' interest.

$\mathrm{H}_{7}$ : Perceptions have a positive effect on the use of online trading through students' interest. 


\section{Results and Discussion}

\subsection{Data Collection Procedure}

The results of collecting questionnaires that have been answered by respondents are presented at the level of distribution and response rate table (Table 1). Next, it is presented the result of the validation test result (Table 2). The tables are as follows:

Table 1. Distribution and rate of return of the questionnaire

\begin{tabular}{lll}
\hline No & Information & Questionnaire Number \\
\hline 1 & Distributed questionnaire & 134 \\
2 & Returned questionnaire & 97 \\
3 & The questionnaire that did not return & 37 \\
4 & Incomplete questionnaire & - \\
5 & Processed questionnaire & 97 \\
Response rate & 72.39 \\
\hline
\end{tabular}

Table 2. Validation Test Results

\begin{tabular}{|c|c|c|c|}
\hline \multirow{2}{*}{ Variable } & \multirow{2}{*}{ Statement Items } & \multicolumn{2}{|c|}{ Correlation } \\
\hline & & $\mathrm{r}$ & Sig \\
\hline \multirow{6}{*}{$\begin{array}{l}\text { Attitude } \\
\text { ( X1 ) }\end{array}$} & $\mathrm{X} 1.1$ & 0,808 & 0,000 \\
\hline & $\mathrm{X} 1.2$ & 0,824 & 0,000 \\
\hline & $\mathrm{X} 1.3$ & 0,805 & 0,000 \\
\hline & $\mathrm{X} 1.4$ & 0,844 & 0,000 \\
\hline & $\mathrm{X} 1.5$ & 0,732 & 0,000 \\
\hline & X1.6 & 0,754 & 0,000 \\
\hline \multirow{6}{*}{$\begin{array}{l}\text { Usage Perception } \\
\text { ( X2) }\end{array}$} & $\mathrm{X} 2.1$ & 0,706 & 0,000 \\
\hline & $\mathrm{X} 2.2$ & 0,635 & 0,000 \\
\hline & $\mathrm{X} 2.3$ & 0,736 & 0,000 \\
\hline & $\mathrm{X} 2.4$ & 0,677 & 0,000 \\
\hline & $X 2.5$ & 0,698 & 0,000 \\
\hline & $\mathrm{X} 2.6$ & 0,729 & 0,000 \\
\hline \multirow{6}{*}{$\begin{array}{l}\text { Interest } \\
\text { ( Y1) }\end{array}$} & Z1.1 & 0,736 & 0,000 \\
\hline & Z1.2 & .706 & 0,000 \\
\hline & $\mathrm{Z} 1.3$ & 0,708 & 0,000 \\
\hline & $\mathrm{Z} 1.4$ & 0,688 & 0,000 \\
\hline & Z1.5 & 0,716 & 0,000 \\
\hline & Z1.6 & 0,701 & 0,000 \\
\hline \multirow{6}{*}{$\begin{array}{l}\text { Use of Online Trading } \\
\text { (Y 2) }\end{array}$} & Y1.1 & 0,766 & 0,000 \\
\hline & Y1.2 & 0,738 & 0,000 \\
\hline & Y1.3 & 0,800 & 0,000 \\
\hline & Y1.4 & 0,699 & 0,000 \\
\hline & Y1.5 & 0,668 & 0,000 \\
\hline & Y1.6 & 0,761 & 0,000 \\
\hline
\end{tabular}

Based on Table 1 above, it is known that the total valid samples are 97. Next, Table 2 shows that all correlation values are $r>0.05$ and sig value $0.000<0.05$, which means a strong and direct correlation between all variables. Therefore, it can be declared that the variables are valid, and further testing could be conducted.

\subsection{Reliability Test}

Reliability is an index that shows the extent to which a measuring instrument can be trusted or relied upon. In this study, reliability testing applied Cronbach's Alpha coefficient, with a real level of 5\%. Reliable criteria for an instrument is declared reliable if the Cronbach alpha value > 0.6 (Singarimbun \& Effendi, 2006). The following table (3) shows the instrument reliability test results. 
Table 3. Instrument Reliability Test Results

\begin{tabular}{lll}
\hline Variable & Reliability & \\
& Cronbach 's Alpha Standardized Items & Note \\
\hline Attitude & 0,921 & Very strong \\
Usage Perception & 0,862 & Very strong \\
Interest & 0,871 & Very strong \\
Use of Online Trading & 0,890 & Very strong \\
\hline
\end{tabular}

The data above shows that the Cronbach alpha value is greater than 0,6 . The overall Cronbach alpha value of indicators is greater than 0.6. It means that all reliable variables with indexes are very strong. Therefore, further testing could be conducted.

\subsection{Data analysis}

Analysis of research data using path analysis technique of the SPSS program is presented in the following Table 4.

Table 4. Summary Model ${ }^{\mathrm{b}}$

\begin{tabular}{lllll}
\hline Model & $\mathrm{R}$ & R Square & Adjusted R Square & Std. Error of the Estimate \\
\hline 1 &, $857^{\text {a }}$ &, 735 &, 729 & 2,137 \\
a. Predictors: (Constant), X2, X1 & \\
b. Dependent Variable: Y1 &
\end{tabular}

As can be seen, the R square $\left(\mathrm{r}^{2}\right)$ number is 0.735 . It is used to see the effect of attitude and perception, namely $73.5 \%$, while other factors outside the model influence the remaining $26.5 \%$. With the sample size of 97 , then the magnitude of $\mathrm{c}^{2}$ count is $71.29(97 \times 0.735=71.29)$. Compared to the size of $\mathrm{c}^{2}$ tables, with a significant level of 0.05 , then, it is found that the $\mathrm{c}^{2}$ table is 120.98 . It can be concluded that the first equation model has fulfilled the linearity principle since $c^{2}$ count $<c^{2}$ tables. Further explanation is presented in the following table (5).

Table 5. Summary Model ${ }^{\mathrm{b}}$

\begin{tabular}{lllll}
\hline Model & $\mathrm{R}$ & $\mathrm{R}$ Square & Adjusted R Square & Std. Error of the Estimate \\
\hline $1 \quad, 853^{\text {a }} \quad, 728$ &, 719 & 2,250 \\
a. Predictors: (Constant), Y1, X2, X1 & \\
b. Dependent Variable: Y2 &
\end{tabular}

Based on Table 5 above, the R square $\left(\mathrm{r}^{2}\right)$ is 0.728 . The number is used to look at the influence of attitudes and the perception of online trading use. It is $72.8 \%$, while other factors outside the model influence the remaining $27.2 \%$. With a total $97, \mathrm{c}^{2}$ count is $70.616(97 \times 0.728=70.616)$. Compared to $\mathrm{c}^{2}$ tables, with a significant level of 0.05 , then it is found that the $\mathrm{c}^{2}$ table is 120.98 . It can be concluded that the first equation model has fulfilled the linearity principle since $c^{2}$ count $<c^{2}$ tables. Moreover, the next table presents the calculation of the coefficients.

Table 6. Coefficients ${ }^{\mathrm{a}}$

\begin{tabular}{|c|c|c|c|c|c|}
\hline \multirow{2}{*}{ Model } & \multicolumn{2}{|c|}{ Unstandardized Coefficients } & \multirow{2}{*}{$\begin{array}{l}\text { Standardized Coefficients } \\
\text { Beta }\end{array}$} & \multirow{2}{*}{$\mathrm{t}$} & \multirow{2}{*}{ Sig. } \\
\hline & B & Std. Error & & & \\
\hline \multirow{4}{*}{$\begin{array}{l}\text { X1 } \\
\text { X2 }\end{array}$} & 4,135 & 1,328 & & 3,113 & ,002 \\
\hline & ,413 &, 076 & ,475 & 5,431 &, 000 \\
\hline & ,425 & ,086 & ,430 & 4,925 &, 000 \\
\hline & \multicolumn{5}{|c|}{ a. Dependent Variable: Y1 } \\
\hline
\end{tabular}

Based on table 6, it can be concluded that the standard regression coefficient is 0.475 with $\mathrm{p}=0.000<0.05$,

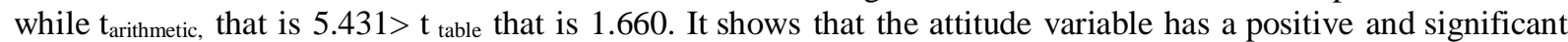
effect on interest. Next, each attitude value has increased by 0.475 . Thus $\mathrm{H}_{1}$ is accepted. This shows that the variable of attitude influences the variable of interest.

Furthermore, Table 6 shows that the regression coefficient standard is 0.430 , with $\mathrm{p}=0,000<0.05$, while $\mathrm{t}$ count is $4.925>\mathrm{t}$ table that is 1.660 . It indicates that the perception variable has significantly influenced the interest. If the value of perception is increased, the interest will also be increased by 0.475 . Thus $\mathrm{H}_{2}$ is accepted. This means that 
the variable of interest is influenced by the perception of the use of online trading. The next finding is presented in the following table (7).

Table 7. Coefficients ${ }^{\mathrm{a}}$

\begin{tabular}{|c|c|c|c|c|c|}
\hline \multirow{2}{*}{ Model } & \multicolumn{2}{|c|}{ Unstandardized Coefficients } & \multirow{2}{*}{$\begin{array}{l}\text { Standardized Coefficients } \\
\text { Beta }\end{array}$} & \multirow{2}{*}{$\mathrm{t}$} & \multirow{2}{*}{ Sig. } \\
\hline & $\mathrm{B}$ & Std. Error & & & \\
\hline (Constant) & 2,598 & 1,469 & & 1,768 &, 080 \\
\hline $\mathrm{X} 1$ &, 325 & ,092 & ,361 & 3,539 & ,001 \\
\hline $\mathrm{X} 2$ & 045 &, 102 & ,044 &, 444 & ,658 \\
\hline Y1 &, 511 &, 109 & ,494 & 4,701 &, 000 \\
\hline
\end{tabular}

Based on table 7, it can be concluded that the standard regression coefficient is 0.361 with $\mathrm{p}=0.001<0.05$, while arithmetic is $3,539>\mathrm{t}_{\text {table }}$ is 1.660 . It shows that the attitude variable has a positive and significant effect on the use of online trading. When each value of attitude increases, the use of online trading also increases by 0,361 . Thus $\mathrm{H}_{3}$ is accepted. This shows that the attitude variable influences the variable of online trading usage.

The table also shows that the standardized regression coefficient is 0.044 , with $p=0,658>0.05$, while $\mathrm{t}_{\text {count }}$ is $0,444<\mathrm{t}_{\text {table }}$ that is 1.660 . It indicates that the variable of perception has no significant effect on the use of online trading. Even each value of perception increases, it does not impact the use of online trading. Thus, it is stated that $\mathrm{H}_{4}$ is rejected. This means that the use of online trading is not influenced by perception.

The last, table 7 also shows that the standardized regression coefficient is 0.494 , with $\mathrm{p}=0,000<0.05$, while $\mathrm{t}_{\text {count }}$ is $4.701>\mathrm{t}$ table that is 1.660 . It indicates that the variable of interest influence positively and significantly to the use of online trading. When each value of interest increases, the use of online trading also increases by 0.494. Thus, $\mathrm{H}_{5}$ is accepted. This shows that the variable of interest influences the variable of online trading usage.

\section{Discussion}

Statistically, the analysis results have shown that the attitude and perception of the use of online trading, partially, in the Capital Market Study Group of Jayapura- Indonesia, have got a positive and significant effect on the use of online trading. The following is the discussion of both direct effect and indirect effect. At the end of the discussion, there is a conclusion made based on the analysis and discussion.

\subsection{Direct Effect}

Attitude variable with a coefficient of 0.001 indicates that an increase in attitude increases online trading. These results indicate that attitude significantly affects online trading in the Capital Market Study Group in Jayapura- Indonesia. The positive attitude of the CMSG traders in Jayapura, undeniable, impacts the use of online trades. The results of this study are following the previous research conducted by Supriono (2015). He states that the attitude has positively and significantly affected the desirability of using the stem of accounting information.

Moreover, the analysis results regarding the direct effect of the perception on the use of online trading revealed that perception of the use of CMSG traders in Jayapura does not affect online trading. These results indicate that the perception of usage does not significantly influence the use of online trading. This study's results do not follow the previous research conducted by Anggraeni (2015), which states that perception has a positive influence and significance to using social media in building networking service.

\subsection{Indirect Effect}

The current study results show that there is an indirect effect of attitude and perception of the use of online trading through mediating interest in the CMSG. The statement is based on the multiplication result between attitude and interest (0.475), online trading (0.494), or summarily $0.475 \times 0.494=0,2346$. Thus, $\mathrm{H}_{6}$ is accepted. Furthermore, based on the multiplication result between the use and interest $(0.430)$, the interest in online trading (0.494), or summarily $0.430 \times 0.494=0212$. Thus, $\mathrm{H}_{7}$ is accepted. The result is shown in the following Figure (2). 


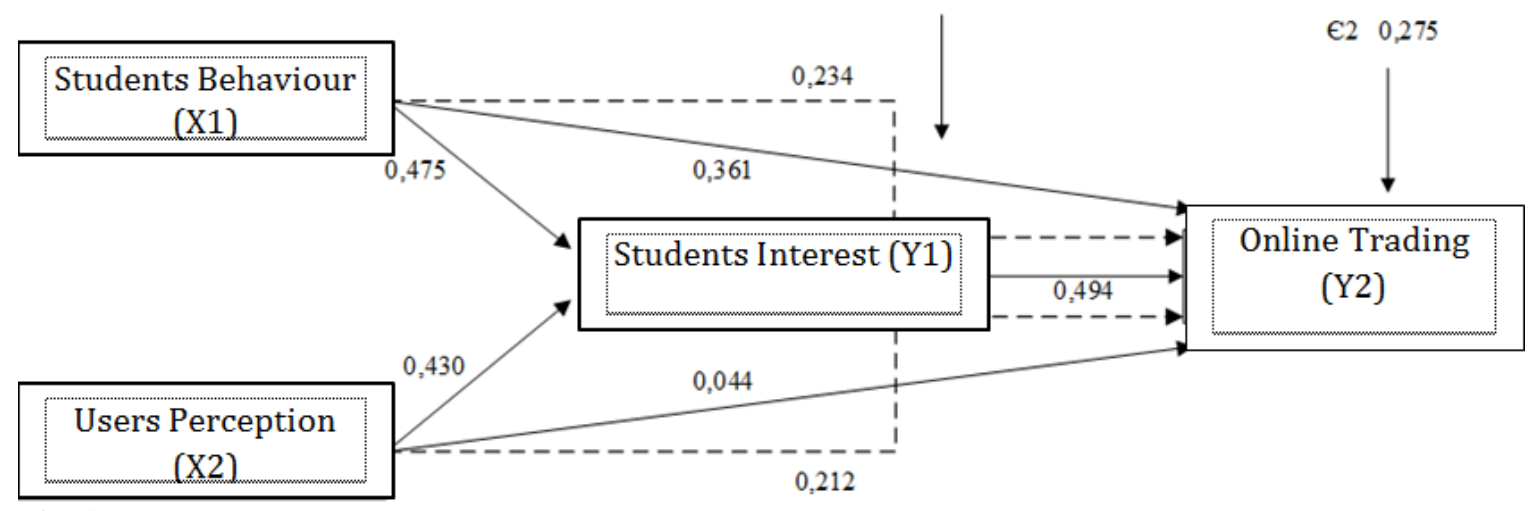

Fig. 2. Indirect Effect of Attitude

Based on the results and the discussion of data analysis, it is concluded that (1) Attitude has a positive and significant effect on interest. This positive influence means that the better the attitude to use online trading. The higher the interest, the use of online trading will be higher. Furthermore, (2) The perception of online trading use has a positive and significant effect on interest. This positive influence means that the better the perception, the higher the interest of using online trading. (3) Attitude has a positive and significant effect on the use of online trading. This positive influence means that the better the attitude, the higher the use of online trading. Next, (4) the perception of online trading use has no significant effect on the use of online trading itself. (5) Interest has a positive and significant effect on the use of online trading. This positive influence means that the higher the interest, the higher the use of online trading. Moreover, (6) the attitude has a positive effect on online trading through interest. This positive influence means that interest has partially mediated the influence of attitudes towards online trading. However, the result shows that it is not dominant. The last, (7) the perception has a positive effect on online trading through interest. This positive influence means that the perception of use mediates the dominant influence of the perception of online trading.

\section{Conclusion}

It is suggested several points as follows. To the related institutions, such as the Indonesia Stock Exchange (IDX) and Stock Securities, it is suggested that they may further increase capital market-related socialization both in terms of capital market introduction and motivation to both Indonesian students and public. Besides, the institutions are suggested to increase cooperation with university students such as CMSG. Next, the university students who are members of the CMSG are suggested to have a positive attitude towards the use of online trading, that is by maximizing the facilities provided by the securities used and building communication between CMSG fellow to share knowledge, experience, and strategies in the capital market, etc. Besides that, the perception of online trading use needs to be improved to be more familiar in using online trading software. For further research, it is suggested to examine the current study model by applying a more diverse population to increase the generalization of research results. Also, it is necessary to add control variables such as gender, age, and education to enrich the research model's results. Future research is suggested to examine other variables that may influence the model, such as motivation, etc.

\section{References}

1. Agustin, P., \& Mawardi, I. (2014). Muslim Investor Behavior in Stock Transaction in the Capital Market. Journal of Sharia Economics Theory and Applied, 1(12).

2. Anggraeni, R. (2015). The Effect of Perception of Ease of Use and Perception of Usefulness on Intention to Use and Actual Use of Location-Based Social Networking Services (Study on Students of the Faculty of Economics and Business, Brawijaya University Malang). Business Economics, 20(1), 1-52.

3. Abu-Rumman, A. (2020). Project Management: a help or hindrance a collaborative research. Al-Balqa Journal for Research and Studies, 23(1), 9-21.

4. Abu-Rumman, A. (2019). Challenging tradition: Exploring the transition towards university entrepreneurialism. Academy of Entrepreneurship Journal, 25(2), 1-15.

5. Abu-Rumman, A., Mhasnah, A., \& Al-Zyout, T. (2021). Direct and indirect effects of TQM on the patients' satisfaction and loyalty in the Jordanian health care sector. Management Science Letters, 11(2), 493-502. https://doi.org/10.5267/j.msl.2020.9.018 
6. Abu-Rumman, A. (2018). Gaining competitive advantage through intellectual capital and knowledge management: an exploration of inhibitors and enablers in Jordanian Universities. Problems and Perspectives in Management, 16(3), 259-268.

7. Abu-rumman, A. (2018). TQM and Competitive Advantage: Experiences within the Engineering, Electronics, and IT Industrial Sectors in Amman. In Excellence in Services 21th International Conference, $0-12$.

8. Ahmed, E.R., Rahim, N.F.A., Alabdullah, T.T.Y., \& Thottoli, M.M. (2019). An Examination of Social Media Role in Entrepreneurial Intention among Accounting Students: A SEM Study. Journal of Modern Accounting and Auditing, 15(12), 577-589.

9. Ahmed, E.R., Alabdullah, T.T.Y., Amran, A., \& Yahya, S.B. (2018). Indebtedness Theory and Shariah Boards: A Theoretical Approach. Global Business and Management Research, 10(1), 127-134.

10. Ahmed, E.R., Islam, A., Alabdullah, T.T.Y., and Amran, A. (2019). A Qualitative Analysis on the Determinants of Legitimacy of Sukuk. Journal of Islamic Accounting and Business Research, 10(3), 342368.

11. Ahmed, E.R., Islam, A., Zuqibeh, A., \& Alabdullah, T.T.Y. (2014). Risks management in Islamic financial instruments. Advances in Environmental Biology, 8(9), 402-406.

12. Ahmed, E.R., Islam, M.A., Alabdullah, T.T.Y., \& bin Amran, A. (2018). Proposed the pricing model as an alternative Islamic benchmark. Benchmarking: An International Journal., 25(8), 2892-2912.

13. Ahmed, E.R., Islam, M.A., \& Alabdullah, T.T.Y. (2018). The moderating role of Shariah supervisory board on sukuk pricing benchmark. International Journal of Excellence in Islamic Banking and Finance, 6(2), 1-32.

14. Alabdullah, T.T.Y., \& Ahmed, E.R. (2019). Board Diversity and Disclosure of Corporate Social Responsibility Link: A Study in Malaysia. Journal of Adv Research in Dynamic \& Control System, 11(11), 1124-1131.

15. Alabdullah, T.T.Y., Ahmed, E.R., \& Muneerali, M. (2019). Effect of board size and duality on corporate social responsibility: what has improved in corporate governance in Asia? Journal of Accounting Science, 3(2), 121-135.

16. Alabdullah, T.T.Y., Ahmed, E.R., \& Nor, M.I. (2018). New Ideas from Management, Finance and Accounting Perspective: The Research for A New Link Between A Company's Outcome and Risk Management. 5th International Conference on New Ideas in Management, Economics and Accounting.

17. Alabdullah, T.T.Y., Laadjal, A., Ries, E., \& Al-Asadi, Y.A.A. (2018). Board features and capital structure in emerging markets. Journal of Advanced Management Science, 6(2). 74-80.

18. Alabdullah, T.T.Y., Nor, M.I., \& Ries, E. (2018). The determination of firm performance in emerging nations: Do board size and firm size matter. Management, 5(3), 57-66.

19. Singh, B., Suman Rajest, S., Praghash, K., Uppalapati, \& Regin, S.R. (2020). Nuclear structure of some even and odd nuclei using shell model calculations. In AIP Conference Proceedings, 2292(1), https://aip.scitation.org/doi/abs/10.1063/5.0030932

20. Bodie, Z., Kane, A., \& Marcus, A. (2008). Investments 8th Edition (8 edition). McGraw-Hill/Irwin. https://www.amazon.com/Investments-8th-Zvi-Bodie/dp/0077261453

21. Datta, D., Mishra, S., \& Rajest, S. S. (2020). Quantification of tolerance limits of engineering system using uncertainty modeling for sustainable energy. International Journal of Intelligent Networks, 1, 1-8. https://doi.org/10.1016/j.ijin.2020.05.006

22. Desfiandi, A., Suman Rajest, S., S. Venkateswaran, P., Palani Kumar, M., \& Singh, S. (2019). Company Credibility: A Tool To Trigger Positive Csr Image In The Cause-Brand Alliance Context In Indonesia. Humanities \& Social Sciences Reviews, 7(6), 320-331.

23. Suresh, P., \& Rajest, S.S. (2019). An analysis of psychological aspects in student-centered learning activities and different methods. Journal of International Pharmaceutical Research, 46(1), 165-172.

24. Venkateswaran, P. S., Sabarirajan, A., Rajest, S.S., \& Rajan, R. (2019). The Theory of the Postmodernism in Consumerism, Mass Culture and Globalization. Journal of Research on the Lepidoptera, Lepidoptera Research Foundation Inc USA, 50(4), 97-113.

25. Singh, B., Kavitha, P., Regin, R., Praghash, K., Sujatha, S., \& Rajest, S. S. (2020). Optimized Node Clustering based on Received Signal Strength with Particle Ordered-filter Routing Used in VANET. Webology, 17(2). 262-277.

26. Lydia, E. L., Kannan, S., SumanRajest, S., \& Satyanarayana, S. (2020). Correlative study and analysis for hidden patterns in text analytics unstructured data using supervised and unsupervised learning techniques. International Journal of Cloud Computing, 9(2-3), 150-162.

27. Ferdinand, A. (2006). Semarang Management Research Methods: Diponegoro University Publishing Agency.

28. Fuller, R.J. (1998). Behavioral finance and the sources of alpha. Journal of Pension Plan Investing, 2(3), 291-293. 
29. Ganguli S., Kaur G., Sarkar P., Rajest S.S. (2020) An Algorithmic Approach to System Identification in the Delta Domain Using FAdFPA Algorithm. In: Haldorai A., Ramu A., Khan S. (eds) Business Intelligence for Enterprise Internet of Things. EAI/Springer Innovations in Communication and Computing. Springer, Cham.

30. Bagale, G., Rajest, S.S., Setiawan, R., Kulkarni, V.D., Al-Odeh, M. Nordin, N.A., Santhose, S.S., \& Raisal, I. (2020). The Impact of Corporate Reputation on Organizational Performance. Productivity Management, 25(1S), 668-681.

31. Gupta J., Singla M.K., Nijhawan P., Ganguli S., Rajest S.S. (2020) An IoT-Based Controller Realization for PV System Monitoring and Control. In: Haldorai A., Ramu A., Khan S. (eds) Business Intelligence for Enterprise Internet of Things. EAI/Springer Innovations in Communication and Computing. Springer, Cham

32. Raisal, I., Rajest, S.S., Kurniullah, A.Z., Kulkarni, A., Nordin, N.A., Setiawan, R., Bagale, G., \& Barman, R.D. (2020). Positive Outcomes of Human Resources Engagement and Impact on Motivation. Productivity Management, 25(1S), 638-667.

33. Adanov, K.B., Rajest, S.S., \& Mustagaliyeva Gulnara, K. (2019). A Short View on the Backdrop of American's Literature. Journal of Advanced Research in Dynamical and Control Systems, 11(12), 182192.

34. Santoso, L.W., Singh, B., Rajest, S.S., Regin, R., \& Kadhim K.H. (2020), A Genetic Programming Approach to Binary Classification Problem. EAI Endorsed Transactions on Energy, 8(31), 1-8. https://doi.org/10.4108/eai.13-7-2018.165523

35. Manurung, A.H. (2012). Behaviour Finance. Economis of Management, 41(4), 1-13.

36. Rashidin, M.S., Javed, S., Liu, B., \& Jian, W. Suman Rajest S.S. (2019). Insights: Rivals Collaboration on Belt and Road Initiatives and Indian Recourses. Journal of Advanced Research in Dynamical and Control Systems, 11(4), 1509-1522.

37. Nofsinger, J.R. (2001). Investment Madness: How Psychology Affects Your Investing And What To Do About It (1st edition). Pearson Education. https://www.amazon.com/Investment-Madness-PsychologyAffects-Investing/dp/0130422002

38. Olsen, R.A. (1998). Behavioral finance and its implications for stock-price volatility. Financial analysts journal, 54(2), 10-18. https://doi.org/10.2469/faj.v54.n2.2161

39. Rajasekaran R., Rasool F., Srivastava S., Masih J., Rajest S.S. (2020) Heat Maps for Human Group Activity in Academic Blocks. In: Haldorai A., Ramu A., Khan S. (eds) Business Intelligence for Enterprise Internet of Things. EAI/Springer Innovations in Communication and Computing. Springer, Cham.

40. Rajest, S.S., \& Suresh, D. (2018). The Deducible Teachings of Historiographic Metafiction of Modern Theories of Both Fiction and History. Eurasian Journal of Analytical Chemistry, 13(4), emEJAC191005.

41. Rao, A.N., Vijayapriya, P., Kowsalya, M., \& Rajest, S.S. (2020). Computer Tools for Energy Systems. In International Conference on Communication, Computing and Electronics Systems, 475-484.

42. Gupta, R.K. (2018). Employment Security and Occupational Satisfaction in India. Journal of Advanced Research in Dynamical \& Control System, 10(10), 244-249.

43. Gupta, R.K. (2019). Minimum Wage and Minimum Work Hour in India. Journal of Advanced Research in Dynamical \& Control System, 11(02-Special Issue), 2402-2405.

44. Gupta, R.K., \& Singh, D.B. (2020). Minimum Wage and Minimum Work Hour in India. The Journey of Single Taxation System: A Comprehensive study of GST in India, International Journal of Disaster Recovery and Business Continuity, 11(03), 3022 -3030.

45. Ritter, J.R. (2003). Behavioral finance. Pacific-Basin finance journal, 11(4), 429-437.

46. Roy Setiawan, Kanchan Rani, Luigi Pio Leonardo Cavaliere, Ngo Tan Hiep, Sudipta Halder, Ismail Raisal, Ruby Mishra, and S. Suman Rajest, "References for Shopping Online Versus in Stores What Do Customers Prefer and How Do Offline Retailers Cope with It?” Productivity Management, Vol.25, No.1S, pp. 874-898, 2020.

47. Sharma M., Singla M.K., Nijhawan P., Ganguli S., \& Rajest S.S. (2020) An Application of IoT to Develop Concept of Smart Remote Monitoring System. In: Haldorai A., Ramu A., Khan S. (eds) Business Intelligence for Enterprise Internet of Things. EAI/Springer Innovations in Communication and Computing. Springer, Cham.

48. Shefrin, H. (2005). A Behavioral Approach to Asset Pricing (1st Editio). USA: Academic Press. https://www.elsevier.com/books/a-behavioral-approach-to-asset-pricing/shefrin/978-0-08-047603-2

49. Singarimbun, M., \& Effendi, S. (2006). Survey Research Methods, LP3ES. Jakarta: PT Pustaka LP3ES Indonesia.

50. Singla M.K., Gupta J., Nijhawan P., Ganguli S., \& Rajest S.S. (2020) Development of an Efficient, Cheap, and Flexible IoT-Based Wind Turbine Emulator. In: Haldorai A., Ramu A., Khan S. (eds) Business 
Intelligence for Enterprise Internet of Things. EAI/Springer Innovations in Communication and Computing. Springer, Cham

51. Suman Rajest S., \& Suresh, P. (2018), Absurd Realism and Structure in Thomas Pynchon's The Crying of Lot 49. In Journal of Advanced Research in Dynamical and Control Systems, 10, (SI11), 571-580.

52. Rajest, S.S., \& Suresh, P. (2018). The Problematizing of History Concentrated on The Poetics of Historiographic Metafiction by Postmodernism and How It Influences Postmodern Fiction. In International Journal of Pure and Applied Mathematics, 119(SI.16), 2457-2469.

53. Rajest, S.S., \& Suresh, P. (2018). Themes and Techniques from Modernism to Postmodernism: The Dubious Continuance of Gravity's Rainbow. International Journal of Pure and Applied Mathematics, 119(SI.16), 2373-2384.

54. Rajest, S.S., \& P. Suresh (2019). The Dialog On Postmodernism Intertextuality, Parody, The Talk of History and The Issue of Reference. International Journal of Recent Technology and Engineering, 7(5C), 244-251.

55. Supriono, S. (2017). The Effect of Attitude, Subjective Norms, Perception of use and Perception of Easy use on the use of Accounting Information System with the Interest of use as Moderation Variables. Journal of Economics and Informatics Engineering, 3(2), 54-68. 